\title{
EBER IN SITU HYBRIDIZATION EXPERIENCE IN HODGKIN LYMPHOMA
}

\author{
Gulen Gul ${ }^{1,2}$, Mehmet Ali Ozcan ${ }^{3}$, Sermin Ozkal ${ }^{4}$ \\ 1 Tepecik Training and Research Hospital, Pathology Department, Izmir, Turkey \\ 2 Dokuz Eylul University, Graduate School of Health Sciences, Basic Oncology, Izmir, Turkey \\ ${ }^{3}$ Dokuz Eylul University, Faculty of Medicine, Hematology Department, Izmir, Turkey. \\ ${ }^{4}$ Dokuz Eylul University, Faculty of Medicine, Pathology Department, Izmir, Turkey.
}

Address for Correspondence: Gulen GUL, E-mail: drguleng@gmail.com

Received: 21.08.2021; Accepted: 24.08.2021; Available Online Date: 20.09.2021

(C) Copyright 2021 by Dokuz Eylül University, Institute of Health Sciences - Available online at https://dergipark.org.tr/en/pub/jbachs

Cite this article as: Gul G, Ozcan MA, Ozkal S. EBER in Situ Hybridization Experience in Hodgkin Lymphoma. J Basic Clin Health Sci 2021; 3: 201- 204.

\begin{abstract}
Purpose: Several studies suggest that the relation of Epstein-Barr virus (EBV) and Hodgkin lymphoma $(\mathrm{HL})$. EBV and $\mathrm{HL}$ associations are reported at rates ranging from $20 \%$ to $100 \%$ that varies nationally and regionally. In this study; in the case of Hodgkin's lymphoma, the presence of EBV encoded RNA (EBER) by in situ hybridization method and it's distribution according to histopathological subtypes were investigated.
\end{abstract}

Methods: We investigated the presence of EBV in Hodgkin Lymphoma diagnosed 107 adult cases between 2013 and 2017, which chromogenic in situ hybridization with EBV RNA probe has been in routine use were evaluated retrospectively with pathology reports.

Results: There were 69 males and 38. Nodular Sclerosis Classical Hodgkin Lymphoma (NSCHL) was the most common (63 cases, 58,9\%) followed by Mixed Cellularity Classical Hodgkin Lymphoma (MCCHL) (23 cases, $21,5 \%)$. EBV was expressed in 40 cases $(45,4 \%)$. High EBV association was found with NSCHL $(50 \%)$ and MCCHL (48\%). None of NLPHL was positive with EBER.

Conclusion: In our series NSCHL is the most common histologic subtype and has higher percentages of EBV positivity as reported in developed countries. Our study has the largest series of patients investigating the relationship between HL and EBER in our country. For further comments more studies, particularly from Turkey, are needed to determine the actual epidemiological pattern of $\mathrm{HL}$ in the region and to define the role of EBV in $\mathrm{HL}$.

Keywords: EBER, EBV, Hodgkin Lymphoma

\section{INTRODUCTION}

Hodgkin's Lymphoma $(\mathrm{HL})$ is a monoclonal lymphoid neoplasm composed of Hodgkin/Reed-Sternberg cells in a background of inflammatory cells consisting of small lymphocytes, histiocytes, neutrophils, eosinophils, plasma cells, and fibroblasts (1). HL has unusually heterogeneous clinical, histologic, and epidemiologic characteristics (1-3). Epstein-Barr virus (EBV), a unique herpesvirus that has been associated with a number of lymphoid malignancies $(2,4)$. Studies have proved a link between EpsteinBarr virüs (EBV) and Hodgkin's disease in adults and children in past decade (1-2, 4-7). The proportion of the subtypes of $\mathrm{HL}$ and EBV positivity shows significant geographic variation worldwide (1-3,8). In this study; in the case of Hodgkin's lymphoma, the presence of EBV encoded RNA (EBER) by in situ hybridization method and its distribution according to histopathological subtypes were investigated.

\section{METHODS}

\section{Review of cases}

Hodgkin Lymphoma diagnosed adult cases between 2013 and 2017, which chromogenic in situ 
Table 1: Distribution of histologic subtypes

\begin{tabular}{|l|l|l|l|l|l|}
\hline & NSCHL (n:63) & MSCHL (n: 23) & LRCHL (n: 10) & CHL unclassifiable (n: 7) & NLPHL (n: 4) \\
\hline Age & $18-76$ & $18-82$ & $23-73$ & $22-76$ & $38-73$ \\
\hline Sex & & & 8 & 1 & 3 \\
Male & 41 & 16 & 2 & 6 & 1 \\
Female & 22 & 7 & 3 & 2 & 0 \\
\hline EBER & 26 & 9 & 4 & 4 & 4 \\
Positive & 26 & 10 & 3 & 1 & 0 \\
Negative & 11 & 4 & 4 & \\
No data & & 4 & 3 & \\
\hline
\end{tabular}

NSCHL: Nodular Sclerosis Classical Hodgkin Lymphoma; MSCHL: Mixed Cellularity Classical Hodgkin Lymphoma; LRCHL: Lymphocyte-rich Classical Hodgkin Lymphoma; CHL: Classical Hodgkin Lymphoma; NLPHL: Nodular Lymphocyte Predominant Hodgkin Lymphoma

hybridization with EBV RNA probe has been in routine use, were evaluated retrospectively with pathology reports. Histologic subtypes according to the WHO classification, age, sex, localization, bone marrow involvement and in situ hybridization (ISH) for EBV encoded RNA (EBER) status were recorded for each patient.

\section{In-situ hybridization (ISH)}

EBV early RNAs (EBER) were investigated by chromogenic ISH method. 4- $\mu$ m thick sections were taken from formalin fixed paraffin embedded tissue samples. Chromogenic ISH with the EBV RNA probe was performed using the standard procedure according to manufacturer's recommendations in full automatic immunohistochemistry and in situ hybridization staining device (Benchmark XT, Ventana Medical Systems, Tucson, USA). For this purpose, oligonucleotide EBV early RNA (EBER) Probe, (INFORM EBER Probe, Ventana Medical Systems, Tucson, USA), and ready-to use ISH kit suitable for probe (ISH iVIEW Blue Detection Kit, Ventana Medical Systems, Tucson, USA) was used.

\section{RESULTS}

Age, sex, localization and bone marrow involvement The range of patient age was 18 to 82 with an average of 44,2 years. There were 69/107 (64.5\%) males and $38 / 107(35,5 \%)$ females. The male: female ratio was $1,8: 1$. The age range for males was 18 to 82 with an average of 45,8 years and for females, the range was 18 to 76 with an average of 41,2 years.

Data on site of lymph node was available in only $54 / 107(50,4 \%)$ cases. The remaining 53 cases was consultation cases. The most common site was the cervical region, accounting for 16 (29,6\%) cases, followed by mediastinal and supraclavicular lymph nodes, accounting for $13(24,07 \%)$ cases of each. Data on bone marrow involvement was available in
$96 / 107(89,7 \%)$ cases. Seven cases $(7,3 \%)$ had bone marrow involvement and two cases was suspicous for bone marrow involvement.

\section{Histopathologic classification}

The distribution of histologic subtypes in the 107 cases reviewed is shown in Table 1. Nodular Sclerosis Classical Hodgkin Lymphoma (NSCHL) was the most common (63 cases, 58,9\%) followed by Mixed Cellularity Classical Hodgkin Lymphoma (MCCHL) (23 cases,21,5\%). There were 10 (9,3\%) cases of Lymphocyte-rich Classical Hodgkin Lymphoma (LRCHL) and 4 (3,7\%) Nodular Lymphocyte Predominant Hodgkin Lymphoma (NLPHL). 7 cases of Classical HL (6,5\%) were unclassifiable subtype.

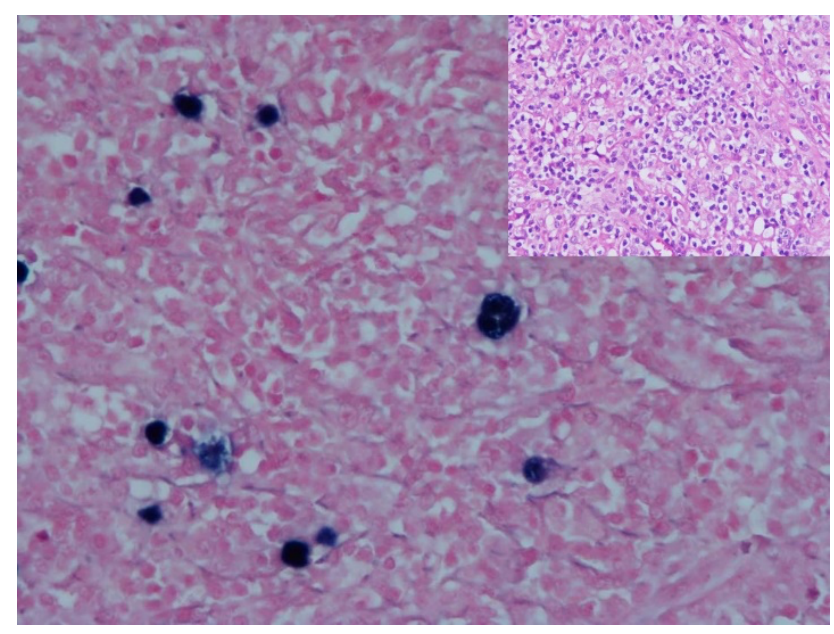

Figure 1. EBER positive HL cells

\section{EBER expression}

EBER results were available in 88 of 107 cases. Fourty cases $(45,4 \%)$ were positive for EBER by ISH (Figure 1). The frequencies of EBV expression in the histological subtypes are summarized in Table 2. EBER was positive in 26/52 (50\%) of NSCHL, 9/19 $(48 \%)$ of MCCHL, but in only $3 / 7(43 \%)$ of $L R C H L$. 
None of NLPHL was positive with EBER. 19 cases had no data of EBER expression. The relation of EBV expression to patient age and gender is also shown in Table 2.

\section{DISCUSSION}

A role for EBV in HL pathogenesis has been further supported by the identification of EBV infection based on Southern blot DNA hybridization, assays for EBERs and immunohistochemical assays for the latency membrane protein-1 (LMP-1) (11). EBV and $\mathrm{HL}$ associations are reported at rates ranging from $20 \%$ to $100 \%$ that varies nationally and regionally $(2,3,9-13)$. The average reported rate in the literature is $40-60 \%(2,3,10,13-14$,$) .$

Most studies described epidemiologic properties of EBV-associated $\mathrm{HL}$, but these reports include tests with different sensitivities and small study samples (2). This may be the reason for the wide range of positivity rates in the literature. However, almost all studies, support that the EBV ratio differs according to age, ethnicity, socioeconomic level and histological subtypes (2-4,9-15). In economically less developed regions, the percentage of EBV positivity in all age groups is higher than in developed regions $(2,3,14)$. Ratios between $30 \%$ and $50 \%$ in developed countries reach $70-100 \%$ in developing countries $(3,11-13)$. EBV prevalence was uniformly higher in children than in young adults for all histologic subtypes (2).

In our study, $45,4 \%$ of cases were EBER positive, similar to developed country rates. But this rate is also lower than the some previous reports from Turkey $(9-12,16)$. This may be due to the fact that we have evaluated a wider series of patients, selected

Table 2: Distribution of EBV expression

\begin{tabular}{|l|l|l|}
\hline & EBER $(+)(\mathrm{n}: 40)$ & EBER $(-)(\mathrm{n}: 48)$ \\
\hline Age & $18-71$ & $20-76$ \\
\hline Sex & & \\
Male & 26 & 31 \\
Female & 14 & 17 \\
\hline Subtype & & \\
NSCHL & 26 & 26 \\
MCCHL & 9 & 10 \\
LRCHL & 3 & 4 \\
CHL & 2 & 4 \\
unclassifiable & 0 & 4 \\
NLPHL & & \\
\hline
\end{tabular}

NSCHL: Nodular Sclerosis Classical Hodgkin Lymphoma MSCHL: Mixed Cellularity Classical Hodgkin Lymphoma LRCHL: Lymphocyte-rich Classical Hodgkin Lymphoma $\mathrm{CHL}$ : Classical Hodgkin Lymphoma

NLPHL: Nodular Lymphocyte Predominant Hodgkin Lymphoma age range (only adult patients, EBV detection method or this could be a regional difference. Only two studies used in situ hybridization for detecting EBV $(9,11)$.

In all age groups, NSCHL had relatively low percentages of EBV-positive cases, whereas MCCHL was associated with high levels (2) In our study NSCHL subtype has the higher percentages of EBV positivity as like the report of Ozdil et. all (11).

In conclusion, in our series NSCHL is the most common histologic subtype and has higher percentages of EBV positivity as reported in developed countries. Our study has the largest series of patients investigating the relationship between $\mathrm{HL}$ and EBER in our country. For further comments more studies, particularly from Turkey, are needed to determine the actual epidemiological pattern of $\mathrm{HL}$ in the region and to define the role of EBV in HL.

Acknowledgement: The study has been presented in 27. National Pathology Congress as a poster.

Conflict of Interest: The authors declare no competing financial interests and no sources of funding and support.

Ethics Statement: The authors confirm that the ethical policies of the journal, as noted on the journal's author guidelines page, have been adhered to. An ethical approval was also obtained from the Dokuz Eylul University Non-Invasive Research Ethics Committee, Izmir, Turkey (Ethics Committee No: 2016/13-26, date: 12/02/2016)

Peer-review: Externally peer-reviewed.

\section{REFERENCES}

1. Stein H, Delsol G, Pileri SA, Weiss L.M, Poppema $S$, Jaffe E. Classical Hodgkin lymphoma, pathology and genetics. In: Swerdlow S, Campo E, Harris N, Jaffe E, Pileri S, Stein H, Thiele J, Vardiman $\mathrm{J}$, editors. WHO Classification of Tumours Pathology \& Genetics: Tumours of haematopoietic and lymphoid tissues. Lyon, France: IARC Press, 2008: 326-329

2. Glaser SL, Lin RJ, Stewart SL, et al. Epstein-Barr virus-associated Hodgkin's disease: epidemiologic characteristics in international data. Int J Cancer. 1997; 70(4): 375-82

3. Makar RR, Saji T, Junaid TA. Epstein-Barr virus expression in Hodgkin's lymphoma in Kuwait. Pathol Oncol Res. 2003; 9(3): 159-65

4. Axdorph U, Porwit-MacDonald A, Sjoberg J, et al. Epstein-Barr virus expression in Hodgkin's disease in relation to patient characteristics, serum factors and blood lymphocyte function. $\mathrm{Br}$ J Cancer. 1999;81: 1182-1187. Available from: 
https://www.ncbi.nlm.nih.gov/pmc/articles/PMC2 374328/pdf/81-6690827a.pdf

5. Weinreb M, Day PJ, Niggli F, et al. The role of Epstein-Barr virus in Hodgkin's disease from different geographical areas. Arch Dis Child. 1996; 74(1): 27-31.

6. Herbst H, Steinbrecher E, Niedobitek G, et al. Distribution and phenotype of Epstein-Barr virusharboring cells in Hodgkin's disease. Blood. 1992; 80(2): 484-91.

7. Pallesen G, Sandvej K, Hamilton-Dutoit SJ, Rowe M, Young LS. Activation of Epstein-Barr virus replication in Hodgkin and Reed-Sternberg cells. Blood. 1991; 78(5): 1162-5.

8. Flavell KJ, Murray PG. Hodgkin's disease and the Epstein-Barr virus. Molecular Pathology. 2000; 53(5): 262-269.

9. Zeytinoğlu A, Hekimgil M, Erensoy $S$, et al. Lenfomalı hastaların dokularında Epstein-Barr Virus DNA ve RNA'sının araştırılması. MiKROBIYOL BÜLT 2005; 39: 473-481 Available from:

http://mikrobiyolbul.org/managete/fu_folder/2005 -04/2005-39-04-473-481.pdf

10. Sadal Benzer E, Demir S, Bilir G, Akçay EY, Arabacı E. Klasik Hodgkin lenfomalarda EBVLMP 1 ekspresyonunun histopatolojik subtiplere göre dağılımı. Ege Tıp Dergisi 2006; 1(45) : 1 - 4 Available from: http://egetipdergisi.com.tr/pdf/pdf_EGE_229.pdf

11. Özdil A, Doğanay L, Demir M, Öz Puyan F, Bilgi S. Detection of Epstein Barr Virus in Hodgkin's Disease in Trakya Region of Turkey; by in Situ Hybridization. Turk J Hematol. 2002; 19(4): 461 464.

12. Kaya H, Erman Z, Gündoğdu C, Tekin SB, Gündoğdu M. Epstein-Barr Virus in Hodgkin's Disease Patients in Northeast Anatolia. Turk $\mathrm{J}$ Hematol. 2000; 17(2): 61-65.

13. Herling M, Rassidakis GZ, Medeiros LJ, et al. Expression of Epstein-Barr virus latent membrane protein-1 in Hodgkin and ReedSternberg cells of classical Hodgkin's lymphoma: associations with presenting features, serum interleukin 10 levels, and clinical outcome. Clin Cancer Res. 2003; 9(6):2114-20.

14. Glavina-Durdov M, Jakic-Razumovic J, Capkun V, Murray P. Assessment of the prognostic impact of the Epstein-Barr virus-encoded latent membrane protein-1 expression in Hodgkin's disease. British Journal of Cancer. 2001; 84(9): 1227-1234.

15. Oudejans JJ, Jiwa NM, Meijer CJ. Epstein-Barr virus in Hodgkin's disease: more than just an innocent bystander. J Pathol. 1997; 181(4): 3536.

16. Yilmaz F, Uzunlar AK, Sogutcu N, Ozaydin M. Hodgkin's disease and association with EpsteinBarr virus in children in Southeast Turkey. Saudi Med J. 2005; 26(4): 571-5. 